\title{
ON THE WATER-SOLUBILITY OF PLANT MINERALS
}

\author{
AARNE MÄKELÄ \\ With the technical assistance of KaIJA Kotilainen \\ Department of Animal Husbandry, University of Helsinki
}

Received July 14, 1967

In plants the minerals appear in inorganic as well as in organic compounds. Among the inorganic compounds sodium-, potassium-, calcium- and magnesiumphosphates, - carbonates, - chlorides and - sulphates are common. Among the organic compounds the salts of organic acids, as for example malic-, oxalic-, aceticand pectic acids, are common. In addition sulphur- and especially phosphoric acid is often found as esters. The occurrence of sulphur as a part of some amino acids is well known.

$\mathrm{Ph}$ os p h o r o s c o m p o n d s. Immediately after absorption phosphorus appears in plants as phosphates, but later on phosphoric acid is bound to organic compounds mainly in the form of esters (BAUMEISTER 1958, p. 486). In green plants the inorganic $\mathrm{P}$ generally makes up the major part of the total amount of phosphorus. The portion is greatest in the leaves. In young leaves there are comparatively many organic phosphorous compounds, particularly nucleoproteins. Manuring with P increases almost exclusively the proportion of inorganic phosphorus (MENGEL 1965, p. 263). REDiske and Biddulph (ref. MENGEL 1965, p. 295) have observed the precipitation of ferriphosphates in the vascular bundles of plants.

The first step in the assimilation of phosphorus seems to be $\mathrm{ph} \mathrm{y} \mathrm{t} \mathrm{i} \mathrm{c} \mathrm{a} \mathrm{c} \mathrm{id,}$ which is encountered as a phosphorus reserve and as a starting-point for different phosphorous compounds. As a phosphorus reserve phytic acid appears as $\mathrm{Ca}-\mathrm{Mg}$ salt, i.e. as phytin, which is insoluble in water. Especially seeds and fruits contain much phytin (BAUMEISTER 1958, p. 486). In addition it is encountered in almost all parts of the plants i.e. in the bulbs, the roots and the leaves. Of the salts of phytic acid only the alcalic salts are soluble in water (DANGSCHAT 1955, p. 64). 
Of the total phospohus in cereal grains some $80 \%$ is bound to phytin. In green parts of plants, however, the proportion of phytin-P of the total phosphorus is only $2 \%$ (Mengel 1965, p. 260). According to Webster (ref. Baumeister 1958, p. 486) the greatest part of the phosphorus in cereal grains is found in phytin and only a small part in lipids and inorganic P-compounds.

The same observation has been made by GARz (1966, p. 148) concerning seeds of peas. According to GARz (1966, p. 139) phytic acid is encountered as watersoluble salts in seeds of peas. According to him the phytic acid of seeds of Leguminosae-plants is possibly partly bound to protein, a major part as K-salt or acid salt and only a minor part as $\mathrm{Ca}-\mathrm{Mg}$ - salt. Of the total phytin in cotyledon meal of peas $88 \%$ is soluble in cold water. Water-soluble phytate has also been encountered in wheat meal. Schmalfuss (1941) has observed that when the grains of maize ripen the inorganic phosphorus is transformed into phytin phosphorus. In the earliest growing stage of the grain the proportion of inorganic phosphorus is approximately $57 \%$ and in the completely ripe grain the proportion of phytin - P is c. $75 \%$ of the total phophorus.

Plantphosphatides are mostly composed of lecithin. Water-soluble phosphatides have been separated from living plants. MAIzEL et al. (1956, p. 407) have observed large amounts, at least $5-20 \%$ of the total phosphorus, of the phosphoric acid ester of choline in the sap of plants. The nucleic a cids are especially important phosphorus containing compounds that are encountered as prosthetic groups in proteins. The phosphoproteins are usually insoluble in water.

$\mathrm{C}$ h l or in e com pound s. Plants absorb chlorine as $\mathrm{Cl}$-ions and in this form it is also encountered in the cell tissues of the plant (VALMARI 1938, p. 149). The amount of chlorine required by plants is usually very small. Chlorine promotes the growth of several plants, especially of those belonging to the Chenopodiaceae-family. Beta-roots, white beet, radish, spinach and celery are chlorophilic plants (MENGEL 1965 , p. 324$)$. In some cases the dry matter may contain as much as $5 \%$ chlorine (HUMPHRIES 1956, p. 487).

Sili c o n c o m p o u d s. Presumably the plants absorb silicic acid as hydrosilicate-ions, $\mathrm{HSiO}_{3}{ }^{-}$(VALMARI 1938, p. 152). Silicic acid is usually stored in plants as amorphous pure $\mathrm{SiO}_{2}$. Using roentgenographic methods $\alpha$-quartz or opal $\left(\mathrm{SiO}_{2}\right.$. $\mathrm{nH}_{2} \mathrm{O}$ ) has been encountered in e.g. Helianthus annums and Triticum-plants (HEINEN 1963, p. 5). ENGEL (ref. HeInEN 1963, p. 6) has extracted galactosesilicate-ester from straws of rye, in which the molar proportion between galactose and silicone in the young material was 1: 1 and in the older material 1: 2. According to Heinen (1963, p. 6) also other carbohydrates (mucilage compounds) can occur instead of galactose. Silicon is always encountered in small amounts in pectin. Polymeric silicic acid has been found in cellulose (Silica-Cellulose).

The solubility of silicic acid decreases as the degree of polymerization increases. Of the silicates only the alcalic silicates are soluble in water; the others are not (HEINEN 1963, p. 7).

Especially rich in silicon $\left(\mathrm{SiO}_{2}\right)$ are horsetails (Equisetum), sedges (Carex) and grasses (Gramineae) (CoLlander 1960, p. 100).

In pure ash of plants belonging to the Cyperaceae- and Equisetaceae-families up 
to $70 \% \mathrm{SiO}_{2}$ can been found (HEINEN 1963, p. 4). Old plants contain more silicon than young ones (MENGEL 1965, p. 322).

$\mathrm{Pot}$ a s s i m com pounds. Plants absorb potassium as $\mathrm{K}^{+}$-ions and in this form it is also encountered in a majority of plants. In fruits, roots and young grass organic acids, as for example citric- and malic acid, are found, except as free acids, also as K-, Na- and Ca-salts. In the cotyledons of peas and beans a major part of the potassium is bound to phytic acid (GARTz 1966, p. 146). Potassium in plants is, even more than magnesium and calcium, found as free ions (COLLANDER 1960, p. 101). Plants differ much less from each other with respect to their $\mathrm{K}$ - than for instance to their Ca- and Si-content (STRIgel 1912, p. 357). It is believed that part of the potassium in plants is contained in ionized form in the proteins of the cell, from where $\mathrm{K}$ can be extracted with water (BAUMEISTER 1958, p. 504). K can easily be extracted from fresh cell tissue with water. K-compounds that are insoluble in water are rare (Humphries 1956, p. 483). For example with tomato- and maizeplants the complete solubility of potassium has been demonstrated. Potato tubers may, however, also contain potassium that is insoluble in water (BAUMEISTER 1958, p. 504). According to Honda and Robertson (ref. Mengel 1965, p. 273) potassium is encountered in insoluble form in mitochondria.

The largest amounts of potassium is encountered in young cell tissue rich in cytoplasm, especially in the growing point and in young leaves as well as in the storage regions of the plant, as for example in potato tubers.

Sodium compounds. Plants absorb sodium as $\mathrm{Na}^{+}$-ions and in this form it is maintained in the cell tissues. Sodium may form salts soluble in water with citric-, malic- and oxalic acid. The Na-content of plants varies considerably. Sodium philic plants, i.e. Beta-roots and spinach, contain $15-20 \mathrm{mg} \mathrm{Na} / \mathrm{g}$ of dry matter, most plants $2-\mathbf{5} \mathrm{mg} / \mathrm{g}$ and sodium phobic plants less than $1 \mathrm{mg} / \mathrm{g}$ of dry matter (Mengel 1965, p. 279).

$\mathrm{C}$ a l c i u m com pounds. Plants absorb calcium as $\mathrm{Ca}^{++}$-ions, in which form it is also encountered in the cell tissues (Collander 1960, p. 101). Of the inorganic Ca-compounds there is plenty of $\mathrm{c} \mathrm{alciu} \mathrm{m} \mathrm{c} \mathrm{a} \mathrm{r} \mathrm{b} \mathrm{o} \mathrm{n} \mathrm{a} \mathrm{t} \mathrm{e} \mathrm{both} \mathrm{in} \mathrm{the}$ protoplasm and the wall of the cell (BAumeister 1958, p. 517). According to MengeL (1965, p. 282) Ca-phosphates and Ca-oxalate exist beside Ca-carbonate in the vacuoles of the cell and as incrusting substances in the cell wall.

$\mathrm{Calcium} \mathrm{sulphat} \mathrm{e}$ is common in the sap of the cell (water solubility $0.2 \%$ ) whereas gypsum crystals are seldom encountered (BAUMEISTER 1958, p. 517).

Of the organic Ca-compounds calcium oxalate in crystal form is common in plants. Of the calcium in sugar beets, sugar beet tops and silage, sugar beet pulp and lucerne meal a considerable part is in the form of calcium oxalate (BRUNe and BREDEHORn 1961, p. 214). According to GARz (1966, p. 141) it is possible that part of the calcium in seeds of beans occurs as oxalate and carbonate.

The rhombic crystals of $\mathrm{calcium}$ t a r t rat e have in some cases been encountered in plant material (BAUMEISTER 1958, p. 517).

$\mathrm{C}$ a l c i u m pect a te occurs in the middle lamella of the cells and in the primary wall of the cell (BAUMEISTER 1958, p. 517). The pectin of the middle lamella of the cells is insoluble in water being saturated with calcium. On the other hand the 
monovalent compounds of calcium are readily soluble (MATson et al. 1951, p. 40). According to Paloheimo (1956, p. 27) the pectin content in the dry matter of sugar beet pulp is c. $50 \%$ and that of young grass sometimes almost $20 \%$.

Calcium may also form a salt with le cit hin. The lecithins form salts soluble in lipides with the divalent- $(\mathrm{Ca}$ and $\mathrm{Mg}$ ) ions. A considerable part of the calcium and magnesium in seeds of Leguminosae-plants is tied to protein and to pectin (GARz 1966, p. 143). Kostytschew and Berg (ref. BAUmeister 1958, p. 516) have observed that of the total amount of calcium in the leaves of white clover (Trifolium repens) $42.4 \%$ is soluble in water and of potato stalks $16.5 \%$. The corresponding figures for seeds of peas and beans are c. 18 and c. $17 \%$ respectively (GARz 1966, p. 143). According to him 54 and $40 \%$ of the total amount of calcium is difficultly soluble (as carbonates and oxalate) in seeds of beans and peas respectively. According to Abutilow (ref. Baumeister 1958, p. 517) water-soluble calcium is primarily found in the topmost youngest parts of the plant, whereas calcium soluble in acid primarily is encountered in the lower parts of the plant.

$\mathrm{M}$ a g n e s i u m c o m p o u n d s. Magnesium in plants is mostly encountered as free ions (Collander 1960, p. 101). Magnesium as a salt (Mg-oxalate, phytin) is free or sorptically bound as an ion or as a chelatic compound (MENGEL 1965, p. 286). Magnesium occurs in the protoplasm of the cells both in inorganic and organic form (Humphries 1956, p. 477). The proportion of chlorophyllmagnesium is c. $20 \%$ of the total amount of magnesium and is not much dependent on the magnesium supply (Popp 1936, p. 129, Michael 1941, p. 80). Hasler et al. (1966, p. 375) have, however, observed that when cultivated grass for cutting contains at least $0.2 \% \mathrm{Mg}$ in the dry matter, the proportion of magnesium bound to chlorophyll is only $10 \%$ or less. A small part of the magnesium appears as a constituent of phytin and of the pectin in the cell wall and of several enzymes. Sometimes Mg-oxalate is encountered (BAUMEISTER 1958, p. 527). In addition $\mathrm{Mg}^{++}$-ions are linked to the phosphate radicals of ribonucleic acid (RNA) (HEwITT 1963, p. 174).

According to GARz (1966, p. 145) 58 and $86 \%$ respectively of the magnesium of the seeds of peas and beans is soluble in water. In the cotyledons of these seeds a considerable part of the magnesium (as well as the potassium) is bound to phytic acid as a water soluble salt.

According to Michael (ref. Baumeister 1958, p. 527) $60-85 \%$ of the total amount of magnesium in leaves of maize is soluble in hot water. The proportion of the water soluble fraction of magnesium is independent of the magnesium supply. In plants magnesium is primarily found in leaves and seeds (BAUMEISTER 1958, p. 527, Humphries 1956, p. 477).

\section{Methods}

By incineration the crude ash can be determined. By subtracting carbon, sand and carbonic acid from the crude ash we get the pure ash (HERManN 1951, p. 25). The analysis of the ash does not give a true picture of the nature and quantities of the minerals of plants because the method of burning to eliminate the organic compounds changes the composition of many minerals. The ash is an artificial product. 
which does not as such form a part of the plant. Only a small part of the compounds included in the ash occurs as such in the plant (PALOHEIMO and MäKEL ̈̈ 1966, p. 241). In addition to the total ash content the present investigation attempts also to determine the valuable constituents ( $\mathrm{P}, \mathrm{K}, \mathrm{Ca}$ and $\mathrm{Mg}$ ) included in it. Special regard has been given to the water-soluble ash and the ash content of the water-soluble fraction of the plant and to the water-soluble portion of the aforementioned cations and phosphorus. In addition, the total amounts of crude protein, chloride and sodium have been determined.

An attempt was made to determine the $\mathrm{tot}$ a l a sh content free from carbon (PALOHEIMO and MäKELÄ 1966).

The water-soluble a sh was determined by burning 3-5 g of ground plant material in an electric oven for $3 \frac{1}{2}$ hours at $550^{\circ} \mathrm{C}$. The ash received in this way was washed into a $250 \mathrm{ml}$ decanter glass with $60 \mathrm{ml}$ of water, boiled $10 \mathrm{~min}$. and filtered. The result of the weighing gives the amount of ash in soluble in water. When this is subtracted from the carbonfree total ash the result gives the watersoluble ash. The method used is similar to those of PeArson $(1962$, p. 21) and Joslyn (1950, p. 94).

To determine the ash content of the water-soluble fraction of $\mathrm{t} \mathrm{h} \mathrm{e} \mathrm{pla} \mathrm{n} \mathrm{t,} 5 \mathrm{~g}$ of the sample is put in an Erlenmeyer flask and $500 \mathrm{~g}$ destilled water and a magnet are added. With a magnetic stirrer the contents are slowly stirred without heating for 2 hours. Then the contents of the Erlenmeyer flask are filtered through a Büchner funnel containing a filter paper (WhatMan No 2) the size of the bottom of the funnel. The precipitate including the filter paper is transferred to a big porcelain bowl, which thus contains the fraction of the plant insoluble in water plus the cations and anions insoluble in water. The filtrate on the other hand contains the water-soluble fraction of the plant plus its cations and anions. Both fractions of the sample are completely evaporated and burnt in an electric oven at $550^{\circ} \mathrm{C}$ for $3 \frac{1}{2}$ hours. In order to be able to determine the water-soluble fraction of the plant the ash contents of the insoluble fraction has to be weighed. The ash content of the water-soluble fraction $=$ carbonfree total ash - the ash content of the insoluble fraction. The cation and phosphorus determinations are made both for the water-soluble and insoluble fractions. In this connection the sum of the soluble and insoluble cation and phosphorus amounts was observed to be approximately equal to the result obtained when the total amount was determined. The proportion of water-soluble cation and phosphorus has been expressed as a percentage of the sum of water-soluble and insoluble fraction. The total amounts of the cations $\mathrm{K}, \mathrm{Na}$, $\mathrm{Ca}$ and $\mathrm{Mg}$ as well as their water-soluble and insoluble portions were determined with a model DU Beckman flame spectrophotometer with photomultiplier attachment. The phosphorus determination was made according to NaumanN (1962,p. 74). This method is approximately the same as those presented by WIEGNERPallman $(1938$, p. 96) and Nehring $(1960$, p. 114). The protein determination was carried out using the KJELDAHL-method. The chlorine d e termin a tion was made according to Humphries (1956, p. 487).

When preparing the samples, chopped plantmaterial was kept in a thermostat at $90-95^{\circ} \mathrm{C}$ for 24 hours and then finely ground. On the other hand slices of roots 
and potato were held at $70^{\circ} \mathrm{C}$ for 24 hours in a vacuum drying apparatus where after they were finely ground.

As each method of analysis was taken into use several determinations were run simultaneously. When the determinations have given approximately the same results only one sample has been used for the analysis. The plantmaterial for the investigation of the mineral compounds was collected primarily from the University of Helsinki Experimental Farm Viik. The samples have been collected from the fields and edges of the farm from areas as free from dust as possible.

\section{Results and conclusions}

The results of the investigation are presented in tables 1, 2 and 3 . They contain figures expressed as percentages of the dry matter of the respective compounds on the total ash, the water-soluble ash, the ash of the water-soluble fraction, the crude protein, $\mathrm{P}, \mathrm{Cl}, \mathrm{K}, \mathrm{Na}, \mathrm{Ca}$ and $\mathrm{Mg}$. In the following when for example the watersoluble phosphorus and potassium is mentioned, it applies to that part of these elements, which is contained in the soluble fraction of the investigated sample. Correspondingly e.g. the water-solubility of phosphorus means a percentage expressing how great an amount of the total phosphorus content is contained in the water-soluble fraction. On the other hand the water-soluble ash refers to the proportion of the ash that dissolves when ash is dissolved in water. The ash of the watersoluble fraction scarcely needs to be further explained.

Excluding $\mathrm{Cl}$ and $\mathrm{Na}$ the water-solubility of the different elements is reported. The corresponding figure for $\mathrm{Cl}$ is not given because the total amount of $\mathrm{Cl}$ occurs in water-soluble form. The water-solubility of $\mathrm{Na}$ is not given because the results of the investigation in this respect proved to be quite uncertain, apparently due to the very small proportions in the examined samples. It may, however, be mentioned that the investigated samples contain much more water-soluble $\mathrm{Na}$ than insoluble $\mathrm{Na}$. The proportions of crude protein have been included because they in some respects characterize the quality of the product. The water-soluble fraction of the ash and the useful minerals reflects the most valuable part of the minerals as for as animal and human nutrition is concerned. This fraction does not, however, contain all the valuable mineral elements of the food. Many minerals soluble in acid but not in water, e.g. di- and triphosphates of calcium and magnesium, calcium- and magnesiumcarbonates, calciumoxalate and many organic esters of phosphoric acid, are important in nutrition. In addition, by determining the water-soluble fraction of the minerals, some information on the nature of mineral compounds is received. The investigated material represents a variety of quite different groups of plant products.

Consequently, it is understandable that common characteristics are rare. In the tables we find the following border values, with the respective border values of the water-solubility given in parantheses. 


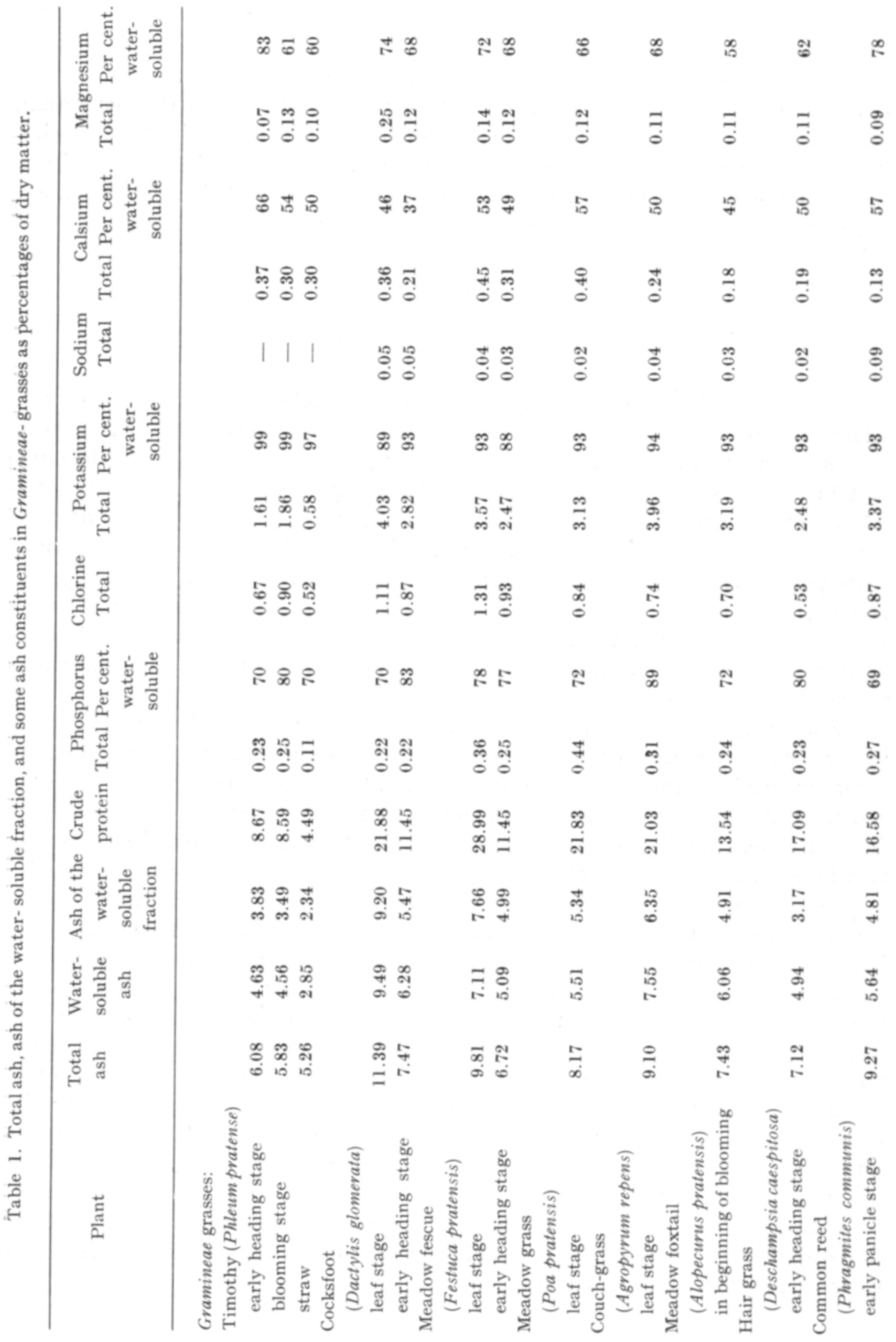




$\begin{array}{llc}\text { Total ash } & 1.82-23.95 & (0.35-16.39) \\ \text { Ash of the water- soluble fraction } & 0.24-11.79 & \\ \text { Phosphorus } & 0.02-1.11 & (31-91 \%) \\ \text { Chlorine } & 0.04-2.62 & \\ \text { Potassium } & 0.20-6.82 & (54-99 \%) \\ \text { Sodium } & 0.02-0.29 & \\ \text { Calcium } & 0.05-1.90 & (4-88 \%) \\ \text { Magnesium } & 0.03-0.57 & (9-83 \%)\end{array}$

In all investigated cases the water-solubility of $\mathrm{K}$ is greater than that of $\mathrm{P}, \mathrm{Ca}$ and $\mathrm{Mg}$. Excluding lichen and grain products, the water-solubility of $\mathrm{K}$ varies between $82-99 \%$ being in most cases over $90 \%$. The next in order after $\mathrm{K}, \mathrm{Na}$ and $\mathrm{Cl}$ are phosphorus and magnesium, the solubility of which in all cases is less than that of K. With the exception of some grain products and lichen, the solubility of $\mathrm{Ca}$ is less than that of $\mathrm{P}$.

Gramineae-grasses. The mineral contents of the most important grasses in Finland for cutting and pasture, are presented in Table 1. Timothy, cocksfoot, meadow fescue and meadow grass have grown on intensively manured fields, whereas the others are natural edge plants. Timothy, cocksfoot and meadow fescue have two or three growth stages. It can be seen that the total ash content decreases as the plant grows older. The proportion of ash of the water-soluble fraction as well as that of the water-soluble ash in the total ash, however, remain almost unchanged. When the plant grows older the crude protein content of the dry matter decreases considerably. The same is also true of the contents of P, K, Ca and Mg. Kerguelen (1960, p. 206) has observed that when the leaves of perennial Gramineae-grasses grow older their content of $\mathrm{Si}, \mathrm{Mg}$ and $\mathrm{Ca}$ increases while the content of $\mathrm{P}, \mathrm{K}$ and $\mathrm{Na}$ decreases. GuÉguen and FAUCONnEAU (1960, p. 157) have observed that later cuttings of cocksfoot grass at the same stage of growth contain more $\mathrm{P}, \mathrm{Ca}, \mathrm{Na}$ and $\mathrm{Mg}$ and less $\mathrm{K}$.

Generally the content of water-soluble ash of the total ash of grasses for cutting and pasture is $70-80 \%$, being however considerably less in reed and ripe timothy. The proportion of ash of the water-soluble fraction is usually somewhat less than that of the water-soluble ash. Seventy to eighty per cent. of the phosphorus is watersoluble. The water-soluble phosphorus is probably to a great extent in inorganic form ( $\mathrm{K}$ - and $\mathrm{Na}$-phosphates and $\mathrm{Ca}$ - and $\mathrm{Mg}$-monophosphates); in addition they occur as alcalic salts of phytic acid and, originating from the photosynthesis, as sugarphosphates and as intermediate products of this synthesis. A considerable amount of the insoluble phosphorus occurs as a $\mathrm{Ca}$ - $\mathrm{Mg}$ - salt of phytic acid, which is encountered in almost all parts of the plant, e.g. in the leaves. Almost all of the potassium is in water-soluble form, mostly as a $\mathrm{K}^{+}$-ion and also occurs sorptically linked with the proteins of the cell or with the water-soluble phytic acid. Only about one half of the calcium is in water-soluble form, probably as $\mathrm{Ca}^{++}$-ions (i.e. as chlorides, monophosphate and bicarbonate). Even such a difficultly soluble Cacompound as $\mathrm{CaSO}_{4}$ (water solubility $0.2 \%$ ) occurs in plants in water-soluble form with the exception of a few rare cases. The insoluble $\mathrm{Ca}$ occurs partly in inorganic form i.e. as Ca-carbonate, Ca-phosphate and $\mathrm{Ca}$-oxalate in the incrusting substances 


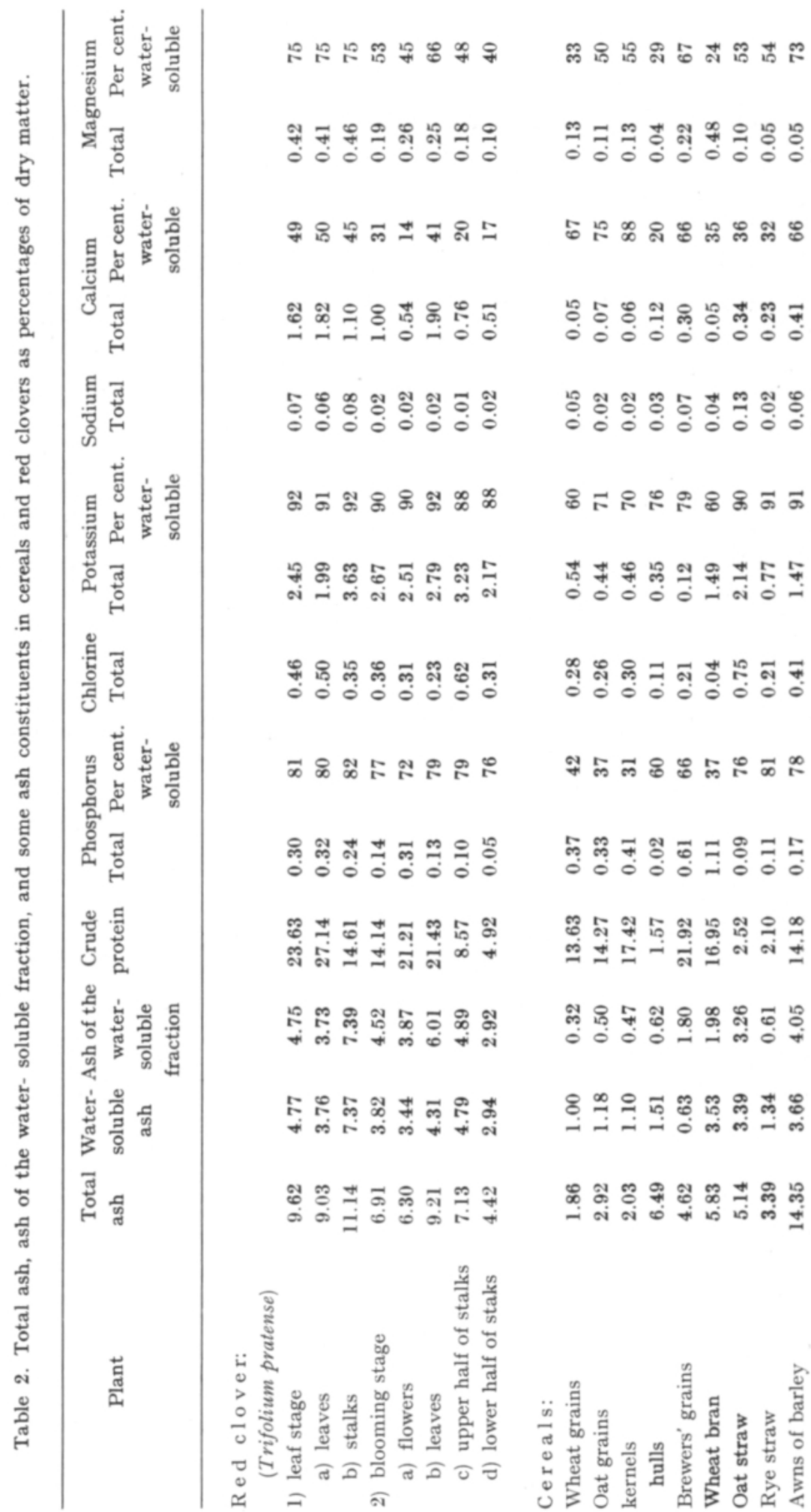


of the cell wall. A considerable, if not the greatest, part of the insoluble calcium occurs as calcium pectate of the middle lamella of the cells.

Generally $60-70 \%$ of the magnesium is water-soluble. The greatest part of the water-soluble magnesium occurs as $\mathrm{Mg}^{++}$-ions in the same compounds as the $\mathrm{Ca}^{++}$-ion. Of the insoluble magnesium approximately one half is bound to the chlorophyll. A part occurs as Mg-phytate and as Mg-pectate of the cell wall and sometimes also as Mg-oxalate.

$\mathrm{R}$ e d c love r. The mineral contents of different parts of red clover at different growth stages are presented in Table 2. When the plant grows older the ash content decreases considerably, the contents of water-soluble ash as well as that of the ash of the water-soluble fraction to a lesser degree. Similarly also the contents of crude protein, $\mathrm{P}, \mathrm{Na}, \mathrm{Ca}$ and $\mathrm{Mg}$ decrease considerably, even to one half, as the plant develops from the leaf stage to the blooming stage. On the other hand the $\mathrm{Cl}$-content decreases only slightly and the content of potassium remains the same. GARz (1957, p. 218) has observed even more drastic decreases of $\mathrm{N}$ and $\mathrm{P}$ in lucerne and in the fractions (phosphatide- and nucleic- $\mathrm{P}$ and inorganic $\mathrm{P}$ ) of phosphorus as the plant develops from a seedling of $10 \mathrm{~cm}$ to the blooming stage. The ash content of the stalks of red clover at the leaf stage as well as the contents of the water-soluble ash and the ash of the water-soluble fraction are considerably higher than those of the leaves. On the other hand the reverse is true at the blooming stage. Both at the leaf and blooming stage the contents of crude protein, $\mathrm{P}$ and $\mathrm{Ca}$, of the leaves are considerably higher than those of the stalks; at the blooming stage this is true also for the content of $\mathrm{Mg}$. On the other hand the content of potassium of the stalks is higher than that of the leaves. GUÉGUEN (1959, p. 218) has obtained similar results with lucerne. With regard to the contents of $\mathrm{Na}$ and $\mathrm{Cl}$, no district differences can be observed. The contents of ash, of the ash fractions as well as of $\mathrm{P}, \mathrm{K}, \mathrm{Ca}, \mathrm{Mg}$ and $\mathrm{Cl}$ are $1 \frac{1}{2}-2$ times as high in the upper parts of the stalks than in the lower parts at the blooming stage. The content of $\mathrm{Na}$ at the blooming stage is small both in the leaves and the stalks. The contents of ash and $\mathrm{Ca}$ are lower but the content of $\mathrm{P}$ is higher in red clover flowers than in the leaves. The proportion of water-soluble ash of the total ash in red clover is both at the leaf and blooming stage only $50-55 \%$, i.e. smaller than the corresponding value for the Gramineae-grasses. Especially in the leaves the water-solubility of the ash is small, only slightly more than $40 \%$, while the corresponding value for the stalks is $70 \%$. The water-solubility of phosphorus, $70-80 \%$, is similar, and that of potassium almost the same, about $90 \%$, as for the Gramineae-grasses. According to GARz (1957, p. 218) in lucerne the proportion of inorganic $\mathrm{P}$ is about $2 / 3$ of the total $\mathrm{P}$ during the whole of the growing period. As the inorganic $\mathrm{P}$ is a storage product, one may conclude that it occurs as easily soluble salts. This may also be true for red clover.

The water-solubility of $\mathrm{Ca}$ and $\mathrm{Mg}$, c. 50 and $75 \%$ respectively, of red clover at the leaf stage, is the same and at the blooming stage (for Ca c. $30 \%$ and for $\mathrm{Mg}$ c. $50 \%$ ) less than for the Gramineae-grasses. The water-solubility of Ca of red clover at the blooming stage is especially low, particularly in the flowers and stalks, only $15-20 \%$. Concluding from the fairly high contents of $\mathrm{Ca}-$ and $\mathrm{Mg}$-compounds insoluble in water, the proportions of $\mathrm{Ca}$ - and $\mathrm{Mg}$-carbonate, $\mathrm{Ca}$ - and $\mathrm{Mg}$-pectate, 
possibly, also of Ca- and Mg-salts of lecithin, are encountered in much greater quantities than in the Gramineae-grasses. GUÉGUEN (1949, p. 249) has observed that grasses and leguminous plants generally contain 0.3 and $1.6 \%$ Ca respectively in the dry matter. On the other hand the contents of $\mathrm{P}, \mathrm{K}$ and $\mathrm{Na}$ are about the same.

$\mathrm{C}$ e r e a $1 \mathrm{~s}$. Table 2 furthermore gives the mineral contents of spring wheat and oat grains, some cereal products, and oat and rye straw. In the grains, wheat bran and straw the proportion of the water-soluble ash is considerably higher, generally about twice as high, as the ash content of the water-soluble fraction. This may be due to fact that part of the minerals which in the sample occur as water-insoluble compounds, appear in water-soluble form in the ash. The opposite seems to be true for brewers' grains, the ash content of the latter proportion being about 3 times as high as of the former. The explanation why brewers' grains still contain water-soluble minerals apparently is that they are contained in the juice. The grains contain fairly high, brewers' grains and particularly wheat bran quite high, contents of phosphorus. The water-solubility of phosphorus is, however, only $40 \%$, except for brewers' grains where it is higher. The $\mathrm{P}$ of the cereal grain is to a considerable part contained in phytin insoluble in water; according to Mengel (1965, p. 260) even $80 \%$. Concluding from the scarcity of calcium, all phytic acid is hardly phytin, but part occurs also as water-soluble K-phytate or as an acid salt of phytic acid which - according to GARz (1966, p. 148) - is common in seeds of plants belonging to the Leguminosaefamily. Phytin occurs particularly in the hull of the grain and in the aleuron layer (DANGschat 1955, p. 64) which explains the high content of $\mathrm{P}$ in wheat bran. The contents of $\mathrm{K}$ and $\mathrm{Ca}$ are especially low in cereal grains. The low content of calcium is due to its poor translocation in plants (Mengel 1965, p. 281).

The water-solubility of $\mathrm{K}$ in cereal grains, as well as in brewers'grains and wheat bran, is only $60-80 \%$, which may be due to the incomplete extraction of $\mathrm{K}$ in cold water. The water-solubility of calcium in grains and brewers' grains is fairly high, c. $70 \%$; therefore only a small part of calcium is bound to phytin. On the other hand only $35 \%$ of the calcium in wheat bran is soluble in water. The water-solubility of magnesium in grains is only c. $50 \%$ or less. It is especially low in wheat bran. The ash content of the hulls of oat grains is about 3 times as high as that of the core. On the other hand the quality of the ash as far as animal nutrition is concerned is inferior to that of the core. The awns of barley are to a certain extent similar to the hulls of oats with respect to their mineral content, the ash content of the awns is, however, considerably higher than that of the hulls. Regardless of the poor watersolubility of the ash of the awns their content of water-soluble ash is at least twice as high as that of the hulls of oat. The awns also contain more $\mathrm{P}, \mathrm{K}, \mathrm{Ca}$ and $\mathrm{Cl}$ than the hulls of oat. The straw of oat, excepting $\mathrm{P}$, is richer in minerals than the straw of rye. At the time when the grains ripen the minerals are transferred from the straw to the grains, making the straw poor in minerals (KNowLEs and WATKIN 1931, p. 616).

P o t a t o, r o o t s and t o p s. The mineral contents of potato, roots and tops are presented in Table 3 . The ash content of potato tubers is low, but the watersolubility of the ash high, c. $90 \%$. They are especially deficient in calcium, containing c. $0.1 \%$. The ash content of swede roots and carrots is high and the water-solubility 
of the ash c. $80 \%$; whereas the water-solubility of $\mathrm{Ca}$ and $\mathrm{Mg}$ is quite low. The mineral content and the water-solubility of the minerals of white cabbage is similar to that of roots. The ash contents of tops, spring rape and potato stalks are quite high, but the water-solubility of the ash is only about $60 \%$. The Ca content is very high, but the water-solubility of the Ca of sugar beet tops and potato stalks is quite low. According to BRUNE and KudLich (1958, p. 1) sugar beet tops contain ample supplies of both oxalic acid and pectin appearing as Ca-compounds insoluble in water. The contents of $\mathrm{Mg}$ and $\mathrm{Cl}$ in sugar beet tops and potato stalks are especially high.

$\mathrm{S}$ o m e o t h e r p la n t s. Table 3 also contains figures on some plants belonging to various groups; they usually occur as weeds but also temporarily as food for animals. The dandelion (Taraxacum officinale) is, with respect to its mineral content and the water-solubility of the ash and different minerals, similar to meadow fescue at the leaf stage. Only the water-solubility of $\mathrm{Ca}$ and $\mathrm{Mg}$ is much lower for the dandelion. Compared with red clover at the leaf stage the dandelion has considerably less $\mathrm{Ca}$ and $\mathrm{Mg}$ but also much more $\mathrm{K}$ and $\mathrm{Cl}$. With respect to the contents of ash and $\mathrm{P}$ the differences are negligible. Approximately the same results have been obtained by STRIGEL (1912, p. 357), when comparing the mineral contents of dandelion and leguminous plants. Of the sedges only the results for Carex Goodenowii are presented in the table. It is similar to timothy at the blooming stage with respect to its mineral content; only the amount and water-solubility of phosphorus is less.

The ash content of water horsetail (Equisetum fluviatile) and of the leaf-stalks of common horsetail (E. arvense) is especially high, but the water-solubility of the ash is low, less than $50 \%$. The reason for the low water-solubility of the ash is probably due to the ample quantities of insoluble Si-compounds. The contents of water-soluble ash and of separate minerals in horsetails are approximately the same as in meadow fescue at the leaf stage, except that the horsetails, especially the water horsetail, contain more $\mathrm{Ca}$ and $\mathrm{Mg}$. The water-solubility of $\mathrm{Ca}$ in the horsetails (23 $27 \%$ ) is, however, much lower than in the meadow fescue.

The ash content of chickweed (Stellaria media) is exceptionally high, c. $24 \%$ in the dry matter. The water-solubility of the ash is $68 \%$. Among the cations the high $\mathrm{K}$-content (c. $10 \%$ in the dry matter) is noticeable. The potassium is however far from being completely soluble in water. On account of the high $\mathrm{K}$-content the alkalinity of the ash is exceptionally high, being equivalent to $12.5 \% \mathrm{CaCO}_{3}$ in the dry matter, when the corresponding values for red clover and timothy coming into ear are 8 and 2.5 respectively. With respect to the contents and water-solubility of other minerals the chickweed does not deviate except that the water-solubility of Ca is exceptionally low $(4 \%)$.

Cladonia alpestris is with respect to the mineral content the opposite to chickweed. The ash content is only c. $2 \%$ in the dry matter and at the same time the water-solubility of the ash is very low $(19 \%)$. Also the separate anions and cations are very scare and their water-solubility is poor. 


\begin{tabular}{|c|c|c|c|c|c|}
\hline 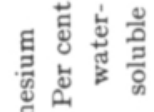 & 옹 ద & ద్లి ద్లి : & $\overrightarrow{0}$ & 尺 & ต์ \\
\hline 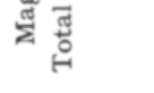 & 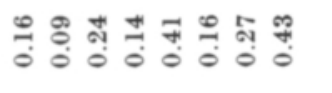 & 突 귱 & $\stackrel{\circ}{\circ}$ & $\stackrel{\infty}{\stackrel{\infty}{+}}$ & 0 \\
\hline 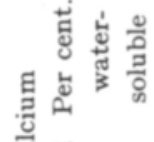 & ద & 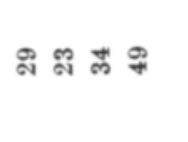 & $\mathscr{a}$ & ล & \\
\hline तुँ స్త్ & 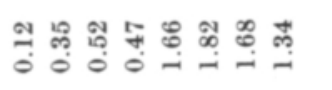 & 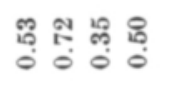 & $\stackrel{\mathscr{q}}{\rightarrow}$ & $\stackrel{\infty}{\leftrightarrow}$ & \\
\hline 朂 & $\begin{array}{c}\stackrel{n}{0} \\
\end{array}$ & 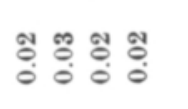 & $\stackrel{0}{\circ}$ & $\stackrel{\oplus}{\circ}$ & 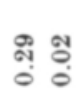 \\
\hline 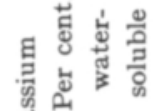 & 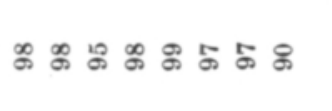 & 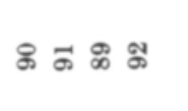 & \& & œ & \& \\
\hline 苂 & †̣ & 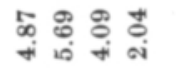 & $\stackrel{\infty}{+}$ & $\stackrel{\text { of }}{10}$ & \\
\hline 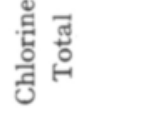 & 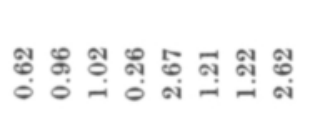 & 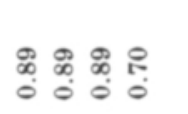 & $\stackrel{\text { ș }}{\circ}$ & $\stackrel{\circ}{\circ}$ & \\
\hline 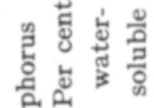 & ホテ எ & 충ํำ & $\bar{\infty}$ & $\stackrel{\infty}{\sim}$ & \\
\hline 萤 & 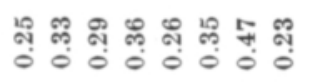 & 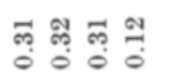 & $\stackrel{9}{\circ}$ & ণ্ণী & 帒 \\
\hline 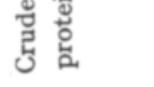 & 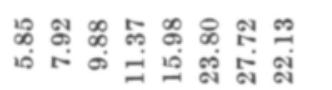 & 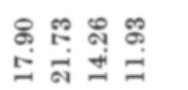 & $\stackrel{\mathscr{q}}{\stackrel{\leftrightarrow}{9}}$ & $\begin{array}{l}\stackrel{\otimes}{0} \\
\stackrel{\oplus}{\oplus}\end{array}$ & 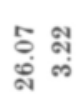 \\
\hline 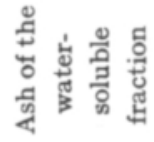 & 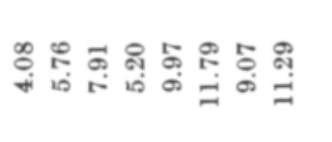 & 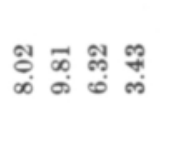 & $\stackrel{9}{\stackrel{9}{r}}$ & $\stackrel{\text { q⿱ }}{\stackrel{9}{9}}$ & S. \\
\hline 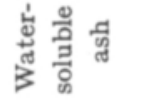 & 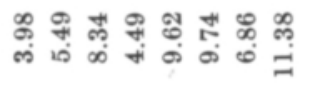 & 迢 \& & ్ֻల్ & $\stackrel{\varphi}{\circ}$ & 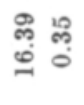 \\
\hline 胥 g & 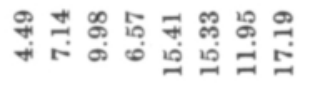 & 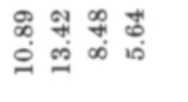 & $\stackrel{\text { ọ }}{\oplus}$ & $\stackrel{\mathscr{P}}{\stackrel{9}{g}}$ & 突 \\
\hline 워 & 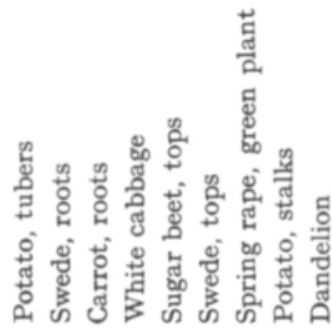 & 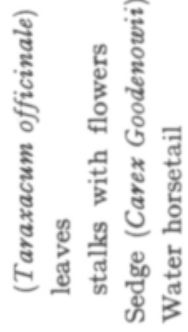 & 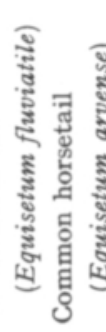 & 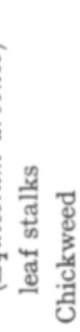 & 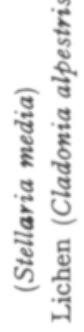 \\
\hline
\end{tabular}




\section{$S u m m a r y$}

This paper deals with ash and mineral contents essential in the nutrition of livestock and man. The results of the investigated products are presented in Tables. $1-3$. Of the minerals the ash and the water-soluble part of it were determined, as well as the ash of the water-soluble fraction and the cations and anions $\mathrm{P}, \mathrm{Cl}, \mathrm{K}, \mathrm{Na}$, $\mathrm{Ca}$ and $\mathrm{Mg}$. The determination of the water-solubility to some extent characterizes. in what form the minerals occur in the plant. The following results were obtained in the determinations of the contents of total ash and the water-solubility.

1. As the Gramineae-grasses grow older the contents of ash and of individual minerals decrease, while the water-solubility simultaneously slightly declines (Table 1). The water-solubility of the ash and $\mathrm{P}$ is $70-80 \%$, that of $\mathrm{K}$ almost complete, that of $\mathrm{Ca} \mathrm{c.} 50 \%$ and that of $\mathrm{Mg}$ in general $60-70 \%$.

2. When red clover develops from the leaf stage to the blooming stage the contents of ash, N, P, Na, Ca and Mg decrease considerably, even to one half, while the content of $\mathrm{K}$ remains unchanged (Table 2). Simultaneously one can observe a decrease in the water-solubility. The water-solubility of the ash is $50-55 \%$, that of $\mathrm{P} 70-80 \%$, that of $\mathrm{K}$ almost complete, that of $\mathrm{Ca} 30-50 \%$ and that of $\mathrm{Mg}$ $50-70 \%$. The contents of $\mathrm{N}, \mathrm{P}$ and $\mathrm{Ca}$ in the leaves are considerably higher than in the stalks; at the blooming stage this is true also for $\mathrm{Mg}$. On the other hand the content of $\mathrm{K}$ in the stalks is higher than in the leaves. The mineral content of the flowers is similar to that of the leaves, except that the content of ash is lower and that of phosphorus higher.

3. The water-solubility of the ash of cereal grains, cereal products and straws. is $40-60 \%$ (Table 2 ). The water-solubility of $\mathrm{P}$ in grains and wheat bran is c. $40 \%$, in brewers' grains and straw $60-80 \%$. The water-solubility of $\mathrm{K}$ is only $60-80 \%$. except in straw where it is $90 \%$. The water-solubility of $\mathrm{Ca}$ in grains and brewers' grains is c. $70 \%$, in the wheat bran and straw $30-40 \%$, in hulls of oats $20 \%$ and awns of barley $66 \%$. The water-solubility of $\mathrm{Mg}$ in brewers' grains is almost $70 \%$. in oat grains and straw c. $50 \%$, in wheat grains and bran $20-30 \%$.

4. The water-solubility of the ash of roots and potato (Table 3) is high, 80$90 \%$. The ash content of tops and potato stalks is quite high, but the water-solubility of the ash only approximately $60 \%$. The water-solubility of $\mathrm{P}$ of the aforementioned plants and parts of plants is $70-90 \%$ and that of $\mathrm{K}$ almost complete. The watersolubility of $\mathrm{Ca}$ in potato tubers, swede tops and spring rape is c. $50 \%$, where as it is low in other plants, especially in sugar beet tops and potato stalks. The watersolubility of $\mathrm{Mg}$ in potato tubers and tops is c. $70 \%$, whereas it is low in carrots, potato stalks and especially in swede roots.

5. In Table 3 are furthermore presented the mineral contents of some plants belonging to various groups of plants which to a limited extent may be used by some animals. The dandelion (Taraxacum officinale) is quite similar to the meadow fescue at the leaf stage with respect to its mineral content and the water-solubility of various: minerals. The common sedge (Carex Goodenowii) is with respect to its mineral content and the water-solubility of the minerals similar to the blooming timothy, except that the amount and water-solubility of $\mathrm{P}$ is low. 
The water-soluble ash and the contents and water-solubility of various minerals of water horsetail (Equisetum fluviatile) and common horsetail (E. arvense) are approximately the same as those of the meadow fescue at the leaf stage, except that the contents of $\mathrm{Ca}$ and $\mathrm{Mg}$ are higher and the water-solubility of $\mathrm{Ca}$ considerably less. The ash content of chickweed (Stellaria media) (c. $24 \%$ in the dry matter) and of its specific minerals, the content of $\mathrm{K}$ (c. $10 \%$ ) is exceptionally high. On the other hand lichen (Cladonia alpestris) is especially poor in minerals.

Acknowledgements. This investigations has been supported by a grant from August Johannes ja Aino Tiuran maatalouden tutkimussäätiö. I wish to acknowledge this grant with sincere gratitude.

\section{REFERENCES}

Baumeister, W. 1958. Hauptnährstoffe. Handb. Pfl. physiol. IV: 482-557. Berlin Göttingen Heidelberg.

Brune, H. \& BREDehorn, H. 1961. Zur Physiologie des bakteriellen Calciumoxalatabbaues und der Verwertungsmöglichkeit von Calcium aus Calciumoxalat beim Schwein. Z. Tierphysiol. Tierenähr. Futtermittelkunde 16: 214-236.

- - \& KUdLich, O. 1958. Zur Calciumverwertung aus Calciumoxalat unter dem Einfluss von Pektin beim Wiederkäuer. Ibid. 13: 1-13.

Collander, R. 1960. Kasvifysiologian alkeet. 278 p. Helsinki.

Dangschat, G. 1955. Inosite und verwandte Naturstoffe. Moderne Methoden der Pflanzenanalyse II: 6494. Herausgegeben von K. PAECH \& M. V. Tracey. Berlin, Göttingen und Heidelberg.

Garz, J. 1957. Zur Kenntnis der Phosphaternährung der Luzerne. Z. Pflanzenernähr. Düng. Bodenkunde 79: 213-232.

- 1966. Menge, Verteilung und Bindungsform der Mineralstoffe (P, K, Mg und $\mathrm{Ca}$ ) in den Leguminosensamen in Abhängigkeit von der Mineralstoffumlagerung innerhalb der Pflanze und den Ernährungsbedingungen. Kühn Archiv 2, 80: 137-194.

GUÉGUEN, L. 1959. Étude de la composition minérale de quelques espèces fourragères. Influence du stade de développement et du cycle de végétaion. Ann. Inst. Nat. Rech. Agr. D. Ann. Zoot. 8: $245-268$.

- - \& FAUConneAU, G. 1960. Étude sur les variations des teneurs en matières azotées et en éléments minéraux du dactyle. Ibid. 9: 157-179.

Hasler, A. \& Schleiniger, J. \& Schnetzer, H. L. 1966. Beitrag zur Kenntnis des Magnesiumgehaltes schweizerischen Wiesenfutters. Schw. Landwirtsch. Forsch. 5: 375-392.

Heinen, W. 1963. Siliciumverbindungen. Moderne Methoden der Pflanzenanalyse 6:4-20. Begründet von K. PAEch \& M. V. Tracey. Berlin, Göttingen und Heidelberg.

HerrmanN, R. 1951. Handbuch der lantwirtschaftlichen Versuchs- und Untersuchungsmethodik (Methoden Buch). 230 p. Radebeul und Berlin.

Hewitr, E. J. 1963. The essential nutrient elements: requirements and interactions in plants. Pl. Physiol. III: $137-360$. Edited by F. C. Steward. New York and London.

Humphries, E. C. 1956. Mineral components and ash analysis. Modern methods of plant analysis I: 468 502. Edited by K. PAECH \& M. V. Tracey. Berlin, Göttingen and Heidelberg.

JosLyn, M. A. 1950. Methods in food analysis. Applied to plant products. 525 p. New York 10, N. Y. Kerguelen, M. 1960. Aspects des variations de la composition de quelques fourrages en fonction des espèces, des stades de végétation, des conditions de sol et de ferilisation. Ann. L'amélioration des plantes 10: $177-236$. 
Knowles, F. \& Watkin, J. E. 1931. The assimilation and translocation of plant nutrients in wheat during growth. J. Agr. Sci. 21: 612-637.

Maizel, J. V. \& Benson, A. A. \& Tolbert, N. E. 1956. Identification of phosphorylcholine as an important costituent of plant saps. Pl. Physiol. 31: 407-408.

Mattson, S. \& Ákerberg, E. \& Eriksson, E. \& Koutler-Andersson, E. \& Vahtras, K. 1951. Factors determining the composition and cookability of peas. Acta Agric. Scand. 1: 40-61.

Mengel, K. 1965. Ernährung und Stoffwechsel der Pflanze. 378 p. Jena.

Michael, G. 1941. Uber die Aufnahme und Verteilung des Magnesiums und dessen Rolle in der hőheren grünen Pflanze. Bodenkunde Pfl.nähr. 25: 65-120.

NaUmann, K. 1962. Entwicklung von Untersuchungsmethoden für Futtermittel. Bestimmung von Phosphor in Futtermitteln. Kraftfutter 45: 74.

NeHRING, K. 1960. Agrikulturchemische Untersuchungsmethoden für Dünge- und Futtermittel, Boden und Milch. 310 p. Hamburg und Berlin.

PALOHeimo, L. 1956. Kotieläinhoidon perusteita. 619 p. Jyväskylä.

->- \& MäKelä, A. 1966. Tuhkamääritys rehuanalyysissä. Maatal. ja Koetoim. XX: 241-244.

Prarson, D. 1962. The chemical analysis of foods. 464 p. London.

Popp, M. 1936. Die Düngewirkung der Magnesia. Die Landwirtsch. Vers. Sta. 124: 129-152.

Scнмalfuss, K. 1941. Uber die Wandlungen der Phosphorverbindungen in der reifenden Maisfrucht, insonderheit bei verschiedener Ernährung der Pflanze. Bodenkunde Pfl.nähr. 20 (65): $151-177$.

Strigel, A. 1912. Vergleichende Untersuchungen: A. Uber Mineralstoffaufnahme verschiedener Pflanzenarten aus ungedüngten Boden. B. Über den Einfluss der botanischen Natur, der Herkunf und der Erntezeit auf die chemische Zusammensetzung von Wieseheu. Landw. J. buch 43: 349371 .

Valmari, J. 1938. Maanviljelyskemian perusteita. 324 p. Porvoo Helsinki.

Wiegner, G. \& Pallman, H. 1938. Anleitung zum quantitativen agrikulturchemischen Praktikum. 389 p. Berlin.

SELOSTUS:

KASVIEN KIVENNÄISAINEIDEN VESILIUKOISUUDESTA

AARNe MÄKELÄ

Kotieläintieteen laitos, Helsingin yliopisto

Tässä tutkimuksessa tarkastellaan kotieläinten ruokinnassa ja myös ihmisravitsemuksessa tărkeitten kasvien tuhka- ja kivennäispitoisuuksia. Tutkitut tuotteet nähdään taulukoista $1-3$. Kivennäisaineista on määritetty tuhka ja sen vesiliukoinen osa, kasvin vesiliukoisen fraktion tuhka sekä kationit ja anionit $\mathrm{P}, \mathrm{Cl}, \mathrm{K}, \mathrm{Na}, \mathrm{Ca}$ ja $\mathrm{Mg}$. Vesiliukoisuuden määrittäminen valaisee jossain määrin kivennäisaineiden esiintymismuotoa kasveissa.

Kivennäisaineiden totaali- ja vesiliukoisuuden määrän määrityksissä on päästy seuraaviin tuloksiin.

1. Gramineae -ruohojen vanhetessa tuhkan ja yksityisten kivennäisaineiden pitoisuudet laskevat samalla kuin myös kivennäisaineiden vesiliukoisuus hieman pienenee. Tuhkan ja P:n vesiliukoisuus on $70-80 \%, \mathrm{~K}: \mathrm{n}$ lähes täydellinen, Ca:n n. $50 \%$ ja $\mathrm{Mg}: \mathrm{n}$ yleisimmin $60-70 \%$.

2. Puna-apilan kehittyessä lehtiasteelta kukka-asteelle tuhka-, N-, P-, Na-, Ca- ja Mg-pitoisuudet laskevat huomattavasti, jopa puoleen, K-pitoisuuden pysyessä ennallaan. Samalla on havaittavissa vesiliukoisuuden laskua. Tuhkan vesiliukoisuus on $50-55 \%$, P:n $70-80 \%$ K:n lähes täydellinen, Ca:n $30-50 \%$ ja Mg:n 50-70\%. Puna-apilan lehtien N-, P- ja Ca-pitoisuudet ovat huomattavasti korkeammat kuin varsien, kukka-asteella myös Mg-pitoisuus. Sensijaan varsien K-pitoisuus on korkeampi kuin 
lehtien. Kukkien kivennäispitoisuus muistuttaa lehtien kivennäispitoisuutta paitsi, että tuhkapitoisuus on alhaisempi ja fosforipitoisuus korkeampi.

3. Viljan jyvien, viljatuotteiden ja olkien tuhkan vesiliukoisuus on $40-60 \%$. P:n vesiliukoisuus on jyvissä ja vehnänleseissä n. $40 \%$, mäskissä ja oljissa $60-80 \%$. K:n vesiliukoisuus on vain $60-80 \%$, paitsi oljilla $90 \%$. Ca:n vesiliukoisuus on jyvissä ja måskissä n. $70 \%$, vehnän leseissä ja oljissa $30-40 \%$, kauran kuorissa $20 \%$ ja ohran vihneissä $66 \%$. Mg:n vesiliukoisuus on mäskissä lähes $70 \%$, kauran jyvissä ja oljissa n. $50 \%$, vehnän jyvissä ja leseissä $20-30 \%$.

4. Juuresten ja perunan tuhkan vesiliukoisuus, on korkea, $80-90 \%$. Naattien ja perunan varsien tuhkapitoisuus on sangen korkea, mutta tuhkan vesiliukoisuus on ainoastaan $60 \%: n$ suuruusluokkaa. Edellämainittujen kasvien ja kasvinosien $\mathrm{P}: \mathrm{n}$ vesiliukoisuus on $70-90 \%$ ja $\mathrm{K}: \mathrm{n}$ lähes täydellinen. Ca:n vesiliukoisuus on perunan mukuloissa, lantun naateissa ja kevätrapsissa n. $50 \%$, sensijaan muissa, erityisesti sokerijuurikkaan naateissa ja perunan varsissa alhainen. $\mathrm{Mg}$ :n vesiliukoisuus on perunan mukuloissa ja naateissa n. $70 \%$, sensijaan porkkanan juurissa, perunan varsissa ja erityisesti lantun juurissa alhainen.

5. Lisäksi on määritetty eräitten eläinten ravitsemuksessa văhäisessä mäărin kysymykseen tulevien, eri kasviryhmiin kuuluvien kasvien kivennäiskoostumus. Voikukka (Taraxacum officinale) muistuttaa kivennäiskoostumukseltaan sekä eri kivennäisaineiden vesiliukoisuudeltaan melko lailla nurminadan lehtiastetta. Jokapaikan sara (Carex Goodenowii) muistuttaa kivennäiskoostumukseltaan ja kivennäisliukoisuudeltaan kukkivaa timoteita paitsi, että P:n määrä ja vesiliukoisuus ovat alhaisia.

Järvikortteen (Equisetum fluviatile) ja peltokortteen (E. arvense) vesiliukoinen tuhka ja eri kivennäisaineiden määrät ja liukoisuudet ovat suunnilleen samansuuruiset kuin nurminadan lehtiasteen paitsi, että Ca- ja Mg-pitoisuus on korkeampi ja Ca:n vesiliukoisuus huomattavasti heikompi. Pihatähtimön (Stellaria media) tuhkapitoisuus (n. $24 \%$ kuiva-aineessa) ja yksityisistä kivennäisaineista K-pitoisuus (n. $10 \%$ ) on ainutlaatuisen korkea. Sensijaan alppijäkälä (Cladonia alpestris) on erityisen kivennäisköyhä 